
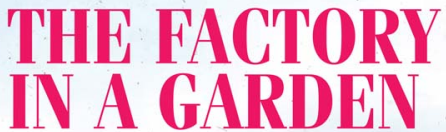

A HISTORY OF CORPORATE LANDSCAPES FROM THE INDUSTRIAL TO THE DIGITAL AGE

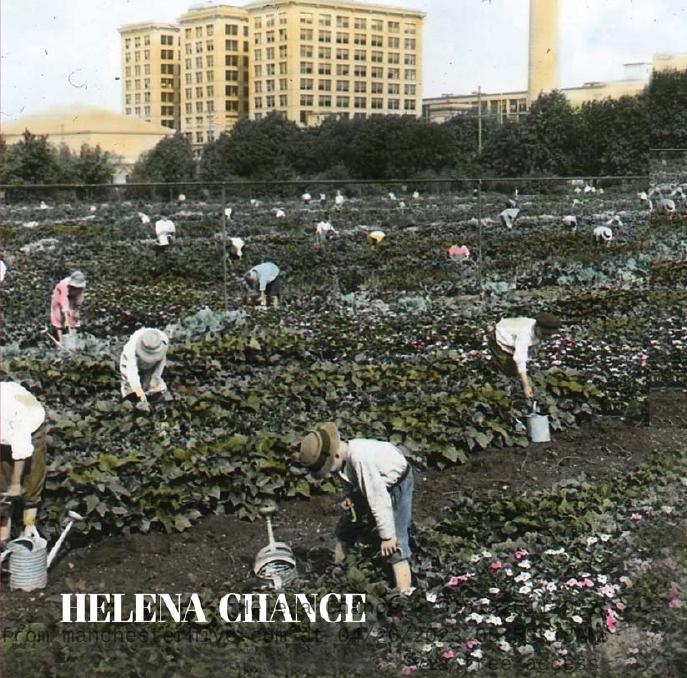




\section{THE FACTORY IN \\ A GARDEN}

\section{MANCHESTER \\ 1824}

Manchester University Press 
also available in the series

The matter of Art

Materials, practices, cultural logics,

c. $1250-1750$

EDITED BY CHRISTY ANDERSON,

ANNE DUNLOP AND PAMELA H. SMITH

Bringing modernity home

Writings on popular design and

material culture

JUDITH ATTFIELD

Design and the modern magazine

EDITED BY JEREMY AYNSLEY AND KATE FORDE

The culture of fashion

A new history of fashionable dress

CHRISTOPHER BREWARD

'The autobiography of a nation'

The 1951 Festival of Britain

BECKY E. CONEKIN

The culture of craft

Status and future

EDITED BY PETER DORMER

Material relations

Domestic interiors and the middle-class

family, 1850-1910

JANE HAMLETT

Arts and Crafts objects

IMOGEN HART

Representations of British motoring

DAVID JEREMIAH

Interiors of Empire

Objects, space and identity within the

Indian Subcontinent, c. 1800-1947

ROBIN JONES

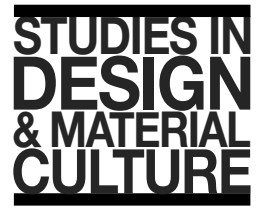

GENERAL EDITOR:

Christopher Breward

and

Glenn Adamson

FOUNDING EDITOR:

Paul Greenhalgh
The Edwardian house

The middle-class home in Britain

1880-1914

HELEN C. LONG

The birth of modern London

The development and design of the city

ELIZABETH MCKELLAR

Interior design and identity

EDITED BY SUSIE MCKELLAR AND

PENNY SPARKE

The material Renaissance

MICHELLE O'MALLEY AND EVELYN WELCH

Bachelors of a different sort

Queer aesthetics, material culture and

the modern interior

JOHN POTVIN

Crafting design in Italy

From post-war to postmodernism

CATHARINE ROSSI

Chinoiserie

Commerce and critical ornament in

eighteenth-century Britain

STACEY SLOBODA

Material goods, moving hands

Perceiving production in England

$1700-1830$

KATE SMITH

Establishing dress history

LOU TAYLOR

The study of dress history

LOU TAYLOR 


\title{
The factory in a garden
}

A HISTORY OF CORPORATE LANDSCAPES FROM THE INDUSTRIAL TO THE DIGITAL AGE

\author{
Helena Chance
}

Manchester University Press 
Copyright ${ }^{\circledR}$ Helena Chance 2017

The right of Helena Chance to be identified as the author of this work has been asserted by her in accordance with the Copyright, Designs and Patents Act 1988.

Published by Manchester University Press

Altrincham Street, Manchester M1 7JA

www.manchesteruniversitypress.co.uk

British Library Cataloguing-in-Publication Data

A catalogue record for this book is available from the British Library

Library of Congress Cataloging-in-Publication Data applied for

ISBN 9781784993009 hardback

First published 2017

The publisher has no responsibility for the persistence or accuracy of URLs for any external or third-party internet websites referred to in this book, and does not guarantee that any content on such websites is, or will remain, accurate or appropriate.

Typeset by

Servis Filmsetting Ltd, Stockport, Cheshire 